\title{
ANALISIS PENGELOLAAN KEUANGAN PEMERINTAH DAERAH KABUPATEN PINRANG
}

\author{
Rustan $^{1}$ Muttiarni $^{2}$ \\ Universitas Muhammadiyah Makassar \\ e-mail : ${ }^{1}$ rustan2011@gmail.com, ${ }^{2}$ muttiani@unismuh.ac.id
}

\begin{abstract}
This research aims to know the financial management of the public sector can support the financial performance of the Government of district Pinrang, the method of data analysis used in this research is a qualitative method. Financial management is calculated based on 5 ratios i.e. regional financial self-reliance ratio, PAD capability, compatibility ratio, and growth ratio. The results showed that the regional financial independence ratio over the past five years resulted in an average number of $3.97 \%$ with an instructive pattern of relationships. Meanwhile, the average PAD capability is only 5.047\% with a pattern of financial capability that is still in intervals of $00.01 \%$ the ability PAD to finance the area's regular expenditure, often referred to by the average IKR (routine capability index) ratio Only 5.047\% with a pattern of financial capability that is still in intervals of $00.01 \%$ the average result of the development ratio of $19.50 \%$ and the routine spending ratio of $8.05 \%$
\end{abstract}

Keywords: Public Sector Accounting, Manufacturing Finance, PAD.

\begin{abstract}
Abstrak
Penelitian ini bertujuan untuk mengetahui pengelolaan keuangan sektor publik dapat mendukung kinerja keuangan pemerintah Kab Pinrang, Metode analisis data yang digunakan dalam penelitian ini adalah metode kualitatif. Pengelolaan keuangan dihitung berdasarkan 5 rasio yaitu rasio kemandirian keuangan daerah, kemampuan PAD, rasio keserasian, dan rasio pertumbuhan. Hasil penelitian menunjukkan bahwa Rasio kemandirian keuangan daerah selama lima tahun terakhir yang menghasilkan jumlah rata-ratanya sebesar 3,97\% dengan pola hubungan yang instruktif. Sedangkan kemampuan PAD rata-rata hanya sebesar 5,047\% dengan pola kemampuan keuangan yang masih berada dalam interval 00,01\% - kemampuan PAD untuk membiayai pengeluaran rutin daerah, yang sering disebut juga dengan Rasio IKR (Indeks Kemampuan Rutin) rata-rata hanya sebesar 5,047\% dengan pola kemampuan keuangan yang masih berada dalam interval 00,01\% - Hasil rata-rata dari rasio pembangunan sebesar 19,50\% dan rasio belanja rutin sebesar 80,50\%.. dan Total Pendapatan Daerah juga mengalami Konstribusi Pendapatan Asli Daerah Kota Makassar terhadap Anggaran Pendapatan dan Belanja Daerah tahun anggaran 2012-2014 dinilai sangat rendah, yaitu 8.05\%.
\end{abstract}

Kata kunci: Akuntansi Sektor Publik, Keuangan Pablik, PAD. 


\section{PENDAhuluan}

Selama satu dekade terakhir, peran sistem pengendalian internal dilingkungan instansi pemerintah mendapat perhatian luas dari para auditor internal, auditor eksternal, penyusun laporan keuangan, asosiasi profesi, dan badanbadan legislatif serta para birokrat. Salah satu isu yang menjadi perhatian adalah banyaknya kejadian yang terkait dengan kegagalan sistem pengendalian internal dalam pengelolaan pemerintahan (Abdullah, 2008). Di lingkungan pemerintah, salah satu permasalahan yang menjadi isunasional adalah masalah penyerapan anggaran yang relatif rendah serta lambatoleh pemerintah pusat dan daerah. Hal ini akan menghambat laju pertumbuhan ekonomi, khususnya di sektor riil dan yang pada akhirnya akan menghambat upaya pemerintah dalam meningkatkan kesempatan kerja dan menekan tingkat kemiskinan (Abdullah, 2008).

Dalam pelaksanaan kegiatan, instansi pemerintah dihadapkan pada ketidakpastian dalam menjalankan kegiatannya yang tentu saja akan berpengaruh pada efisiensi proses kegiatan tersebut, serta efektivitas hasilnya. Untuk mengatasi hal tersebut diperlukan suatu sistem pengendalian internal. Pengendalian internal diperlukan untuk meyakinkan bahwa sebagian besar ketidakpastian, baik dalam pengelolaan keuangan maupun kegiatan telah diperhitungkan pengaruhnya pada pencapaian hasil akhir kegiatan. Sistem inidiharapkan dapat memberi keyakinan terhadap penyelenggara kegiatan padasuatu instansi pemerintah, sehingga dapat mencapai tujuannya secara efisien dan efektif, meningkatkan daya serap anggaran, serta dapat melaporkan pengelolaan keuangan negara secara handal, mengamankan aset negara, dan mendorong ketaatan terhadap peraturan perundang-undangan (Hasmah, 2010).

Keberhasilan mengenali dan mengukur besaran ketidakpastian, baik yang melekat pada instansi pemerintah sampai kepada suatu kegiatan, akan memungkinkan instansi pemerintah untuk memilih berbagai aktivitas pengendalian dalam rangka pengelolaan kegiatan dan resiko, serta pemilihan metode pengelolaan yang tepat yang mampu meyakinkan dapat dikendalikannya proses sehingga sumber daya yang telah dianggarkan dapat diserap dengan tepat waktu dan tepat guna (Abdullah, 2008).

Berubahnya sistem pengelolaan keuangan negara tidak hanya dalam hal penerapan penganggaran, namun juga dalam sistem pencatatan, pertanggungjawaban, dan pengawasan atas akuntabilitas keuangan negara. Perubahan tersebut antara lain di bidang penganggaran keuangan negara, linebased budgeting diganti oleh performance based budgeting yaitu penganggaranyang didasarkan pada kinerja dan berorientasi pada hasil akhir. Di bidang pertanggungjawaban, pencatatan dan pelaporan, keuangan negara tidak lagi dicatat secara single-entry namun diubah berdasarkan kaidah standar akuntansi keuangan yang menerapkan pencatatan secara double-entry dan disajikan dalam bentuk laporan keuangan yang lengkap yaitu neraca, realisasi anggaran, arus kas, dan catatan atas laporan keuangan (Abdullah, 2008).

Sistem pengelolaan keuangan negara yang lebih akuntabel dan transparan memerlukan dukungan sistem pengelolaan keuangan instansi pemerintah secara keseluruhan. Hal ini baru dapat dicapai jika seluruh tingkat pimpinan menyelenggarakan sistem pengendalian internal atas keseluruhan kegiatan diinstansi masingmasing mulai dari pembentukan struktur organisasi yang memisahkan tanggung jawab fungsional secara tepat, penetapan system wewenang dan prosedur pembukuan yang baik, pelaksanaan praktek-praktek sehat dalam melakukan tugas, serta pemberian tanggungjawab sesuai dengan tingkat kecakapan pegawai.

\section{Keuangan Publik}

Keuangan Publik adalah bagian dari ilmu ekonomi yang mempelajari kegiatan keuangan pemerintah. Sektor Keuangan Publik telah mengalami perkembangan dari waktu ke waktu secara dinamis. Sektor Keuangan Publik mempelajari proses pengambilan keputusan oleh pemerintah, karena setiap keputusan pemerintah mempunyai pengaruh yang besar terhadap kegiatan perekonomian. Untuk itu sangatlah penting bagi semua pihak untuk mengembangkan konsep-konsep dasar pengelolaan keuangan publik agar dapat dipergunakan sebagai acuan bagi seluruh fungsi manajemen keuangan negara dan daerah termasuk fungsi pengawasan.

Konsep tersebut mencakup pula semua nilainilai perubahan yang terdapat pada reformasi manajemen keuangan negara dan daerah. Hasil dari reformasi keuangan negara dan daerah 
tersebut antara lain adalah lahirnya paket undangundang di bidang otonomi daerah.

\section{Pengendalian Internal}

Pengertian Sistem Pengendalian Internal menurut PP Nomor 60 Tahun 2008tentang SPIP adalah: "Proses yang integral pada tindakan dan kegiatan yang dilakukan secara terus menerus oleh pimpinan dan seluruh pegawai untuk memberikan keyakinanmemadai atas tercapainya tujuan organisasi melalui kegiatan yang efektif danefisien, keandalan pelaporan keuangan, pengamanan asset negara, dan ketaatanterhadap peraturan perundangundangan." Tujuan Pengendalian internal yang diciptakan dalam suatu perusahaan harusmempunyai beberapa tujuan. Sesuai dengan definisi yang dikemukakan AICPAtersebut di atas, maka dapat dirumuskan tujuan dari pengendalian internal yaitu menjaga keamanan harta milik perusahaan, memeriksa ketelitian dan kebenarandata akuntansi, memajukan efisiensi operasi perusahaan, dan membantu menjaga kebijaksanaan manajemen yang telah ditetapkan lebih (Zaki, 1999).

\section{Kinerja Keuangan Pemerintah Daerah}

Dalam organisasi sektor publik, setelah adanya operasional anggaran, langkah selanjutnya adalah pengukuran kinerja untuk menilai prestasi dan akuntabilitas organisasi dan manajemen dalam menghasilan pelayanan public yang lebih baik. „Akuntabilitas yang merupakan salah satu ciri dari terapan good governance bukan hanya sekedar kemampuan menujukan bagaimana menunjukan bahwa uang publik tersebut telah dibelanjakan secara ekonomis, efektif, dan efisien ${ }^{\text {eee }}$ (Mardiasmo 2002).

\section{Anggaran Pendapatan dan Belanja Daerah (APBD)}

Proses penyusunan anggaran sering kali menjadi isu penting yang menjadi sorotan masyarakat. Pidato Presiden setiap bulan Agustus tentang Nota Keuangan dan Rancangan APBD, misalnya, selalu menjadi indicator perekonomian Negara untuk selama setahun berikutnya. Bahkan, tidak jarangAPBD tersebut menjadi alat politik yang digunakan oleh pemerintah sendiri maupun oleh pihak oposisi. Jika demikian, apakah sebenarnya yang dimaksud dengan anggaran? Bagaimana selukbeluknya? Menurut Mardiasmo (2002), "Anggaran adalah sebuah proses yang dilakukan oleh organisasi sektor publik untuk mengalokasikan sumber yang dimilikinya pada kebutuhan-kebutuhan yang tidak terbatas (the process ofallocating resources to unlimited demands)". Pengertian tersebut mengungkapkan peran strategis anggaran dalam pengelolaan kekayaan sebuah organisasi sektor publik tentunya berkeinginan memberikan pelayanan maksimal kepada masyarakat, tetapi sering kali keinginan tersebut terhambat oleh terbatasnya sumber daya yang dimiliki. Disinilah dituntut peran penting anggaran. Anggaran dapat juga dikatakan sebagai pernyataan mengenai estimasi kinerjayang hendak dicapai selama periode waktu tertentu dalam ukuran finansial.

\section{METODE}

\section{Pendekatan Penelitian}

Pendekatan yang digunakan dalam penelitian ini adalah pendekatan kualitatif. Lokasi penelitian ini dilakukan pada Pemerintah Daerah Pinrang, dengan ruang lingkup penelitian adalah pegawai instansi PemerintahDaerah Kabupaten Pinrang dilakukan selama 2 bulan. Metode pengumpulan data dilakukan dengan menyebarkan kuesioner. Adapun jenis data yang digunakan dalam penelitian ini adalah data kualitatif dan kuantitatof, sedangkan Sumber data yang diperoleh dalam penelitian ini adalah sumber primer dan sekunder.

\section{Metode Analisis Data}

Adapun metode analisis data yang digunakan untuk menguji hipotesis adalah menggunakan metode kualitatif. Metode penelitian kualitatif adalah metode untuk menyelidiki obyek yang tidak dapat diukur dengan angka-angka ataupun ukuran lain yang bersifat eksak. Penelitian kualitatif juga bisa diartikan sebagai riset yang bersifat deskriptif dan cenderung menggunakan analisis dengan pendekatan induktif. Penelitian kualitatif jauh lebih subyektif daripada penelitian atau survei kuantitatif dan menggunakan metode sangat berbeda dari mengumpulkan informasi, terutama individu, dalam menggunakan wawancara secara mendalam dan grup fokus. Teknik pengumpulan data kualitatif diantaranya adalah interview (wawancara), quesionere (pertanyaanpertanyaan/kuesioner), schedules (daftar pertanyaan), dan observasi penyelidikan sejarah 
hidup (life historical investigation), dan analisis konten (content analysis).

\section{HASIL DAN PEMBAHASAN}

\section{Analisis Kinerja Keuangan Pemerintah Kabupaten Pinrang}

Dalam mengukur keberhasilan atau kegagalan suatu organisasi, maka perlu dilakukan pengukuran kinerja. Hal ini dilakukan sebagai upaya perbaikan secara terus menerus guna menunjang keberhasilan di masa yang akan datang. Dalam penelitian ini akan diukur kinerja keuangan pemerintah Kabupaten Pinrang tahun 2012 - 2014. Berikut hasil analisis rasio keuangan pemerintah Kabupaten Pinrang tahun 2012-2014.

\section{a. Rasio Kemandirian Keuangan Daerah}

Kemandirian keuangan daerah merupakan kemampuan pemerintah daerah dalam meningkatkan pendapatan asli daerah (PAD) seperti pajak daerah, retribusi dan lain-lain. Oleh karena itu, otonomi daerah dan pembangunan daerah bisa diwujudkan hanya apabila disertai kemandirian keuangan yang efektif. Ini berarti bahwa pemerintahan daerah secara finansial harus bersifat independen terhadap pemerintah pusat dengan jalan sebanyak mungkin menggali sumber-sumber PAD seperti pajak, retribusi dan sebagainya serta mengoptimalkan sumbersumber PAD yang telah ada.

Rasio kemandirian daerah dihitung dengan menggunakan rumus sebagai berikut:

Rasio Kemandirian

$=\frac{\text { Pendapatan Asli Daerah (PAD) }}{\text { Bantuan Pemerintah Pusat/Provinsi }+ \text { Pinjaman }} \times 100 \%$

Rasio kemandirian daerah Kabupaten Pinrang tahun 2012 adalah sebagai berikut:

Rasio Kemandirian $=\frac{17 \cdot 920.619 .304,26}{524.099 .735 .811,47} \times 100 \%$ $=0,034$ atau $3,4 \%$

Rasio kemandirian daerah Kabupaten Pinrang tahun 2013 adalah sebagai berikut:

Rasio Kemandirian $=\frac{21 \cdot 176.935 .131,33}{601.677 .897 .109,92} \times 100 \%$
$=0,035$ atau 3,5\%

Rasio kemandirian daerah Kabupaten Pinrang tahun 2014 adalah sebagai berikut:
Rasio Kemandirian $=\frac{34.997 .091 .444,53}{690.672 .811 .748,18} \times 100 \%$

$=0,050$ atau $5,0 \%$

Berdasarkan perhitungan di atas, dapat diketahui rasio kemandirian daerah Kabupaten Pinrang tahun 2012-2014. Tabel 5.1 menggambarkan hasil perhiungan dan pola hubungan antara pemerintah pusat dengan pemerintah daerah kabupaten Pinrang.

Tabel 1. Hasil Perhitugan Rasio Kemandiran Kabupaten Pinrang Tahun 2012-2014

\begin{tabular}{lll}
\hline Tahun & Rasio Kemandirian & Pola Hubungan \\
\hline 2012 & $3,4 \%$ & Instruktif \\
\hline 2103 & $3,5 \%$ & Instruktif \\
\hline 2014 & $5 \%$ & Instruktif \\
\hline
\end{tabular}

Sumber : Data Diolah (2016)

Dari tabel 4.1 di atas, dapat diketahui bahwa rasio kemandirian daerah Kabupaten Pinrang tahun 2012 adalah sebesar 3,4\%, tahun 2013 sebesar 3,5\% dan tahun 2014 sebesar 5\%. Hal ini menunjukkan bahwa tingkat kemandirian daerah pada tahun-tahun tersebut sangat rendah dan memiliki hubungan Instruktif, artinya pemerintah daerah masih sangat tergantung dengan bantuan dana dari pemerintah pusat. Selanjutnya hasil perhitungan memperlihatkan bahwa rasio kemandirian daerah Kabupaten Pinrang pada tahun 2012-2014 menunjukkan tren kenaikan. Dalam hal ini kinerja pemerintah daerah cukup baik karena terjadi peningkatan pendapatan asli daerah tiap tahun-tahun tersebut.

\section{b. Rasio Indeks Kemampuan Rutin}

Indeks Kemampuan Rutin (IKR) dapat dihitung dengan menggunakan rumus sebagai berikut:

$$
I K R=\frac{P A D}{\text { Total Pengeluaran Rutin }} \times 100 \%
$$

Dalam penelitian ini, pengeluaran rutin atau belanja rutin diperoleh dari bagian belanja operasi. Hal ini dikarenakan adanya perubahan peraturan mengenai kelompok belanja dalam Peraturan Menteri Dalam Negeri Nomor 13 Tahun 2006 yang kemudian diubah kedalam Peraturan Menteri Dalam Negeri Nomor 59 Tahun 2007 tentang Pedoman Pengelolaan Keuangan Daerah.

Berikut adalah perhitungan rasio indeks kemampuan rutin daerah Kabupaten Pinrang tahun 2012-2014: 
Rasio indeks kemampuan rutin daerah Kabupaten Pinrang tahun 2012 adalah sebagai berikut:

$$
\begin{aligned}
& I K R=\frac{17 \cdot 920 \cdot 619.804 ., 26}{420.113 \cdot 701 \cdot 099,00} \times 100 \% \\
& =0,0426 \text { atau } 4,26 \%
\end{aligned}
$$

Rasio indeks kemampuan rutin daerah Kebupaten Pinrang tahun 2013 adalah sebagai berikut:

$I K R=\frac{21.176 .935 .131,33}{468.987 .945 .106,00} \times 100 \%$
$=0.0451$ atau $4,51 \%$

Rasio indeks kemampuan rutin daerah Kabupaten Pinrang tahun 2014 adalah sebagai berikut:

$I K R=\frac{37 \cdot 641 \cdot 158.766,00}{590.189 .923 .920,00} \times 100 \%$

$=0,0637$ atau $6,37 \%$

Berdasarkan perhitungan di atas, dapat diketahui rasio indeks kemampuan rutin daerah Kabupaten Pinrang tahun 2012-2014. Tabel 5.2 menggambarkan hasil perhiungan rasio indeks kemampuan rutin pemerintah Kabupaten Pinrang.

Tabel 2. Hasil Perhitungan Rasio Indeks Kemampuan Rutin Daerah Kabupaten Pinrang Tahun 2012-2014

\begin{tabular}{lllll}
\hline Tahun & $\begin{array}{l}\text { Rasio } \\
\%\end{array}$ & IKR & $\begin{array}{l}\text { Kemampuan } \\
\text { Daerah }\end{array}$ & Keuangan \\
\hline 2012 & $4,26 \%$ & Sangat Kurang & \\
\hline 2013 & $4,51 \%$ & Sangat Kurang & \\
\hline 2014 & $6,37 \%$ & Sangat Kurang & \\
\hline
\end{tabular}

Sumber: Data Diolah (2016)

Dari tabel 4.2 di atas, dapat diketahui bahwa rasio indeks kemampuan daerah Kabupaten Pinrang tahun 2012 adalah sebesar 4,26\%, tahun 2013 sebesar $4,51 \%$ dan tahun 2014 sebesar $6,37 \%$. Hal ini menunjukkan bahwa indeks kemampuan rutin daerah tahun-tahun tersebut sangat rendah. Selanjutnya hasil perhitungan memperlihatkan bahwa rasio indeks kemampuan rutin daerah

Kabupaten Pinrang pada tahun 2012-2014 menunjukkan tren kenaikan. Dalam hal ini kinerja pemerintah daerah cukup baik karena terjadi peningkatan pendapatan asli daerah tiap tahun-tahun tersebut. Tetapi dalam konteks belanja rutin, kinerja pemerintah daerah kurang baik. Hal ini karena belanja rutin tiap tahuntahun tersebut mengalami peningkatan.

\section{c. Rasio Keserasian}

Rasio keserasian yang digunakan dalam analisis ini menggunakan rumus sebagai berikut:

Rasio Belanja Operasional $=\frac{\text { Total Belanja Operasi }}{\text { Total Belanja APBD }}$

$$
\text { Rasio Belanja Modal }=\frac{\text { Total Belanja Modal }}{\text { Total Belanja APBD }}
$$

Rasio keserasian daerah Kabupaten Pinrang tahun 2012 adalah sebagai berikut:

$$
\begin{aligned}
\text { Rasio Belanja Operasional }= & \frac{420.113 .701 .099,00}{527.100 .625 .244,75} \\
& =0,797 \text { atau } 7,97 \%
\end{aligned}
$$

Rasio Belanja Modal $=\frac{92.859 .950 .409,75}{527 \cdot 100.625 .244,75}$ $=0,176$ atau $1,76 \%$

Rasio keserasian daerah Kabupaten Pinrang tahun 2013 adalah sebagai berikut:

$$
\begin{aligned}
\text { Rasio Belanja Operasional } & =\frac{468.987 .945 .106,00}{589.006 .556 .154,00} \\
& =0,796 \text { atau } 7,96 \%
\end{aligned}
$$

Rasio Belanja Modal $=\frac{103.502 .560 .153,00}{589.006 .556 \cdot 154,00}$ $=0,175$ atau $1,75 \%$

Rasio keserasian daerah Kabupaten Pinrang tahun 2014 adalah sebagi berikut:

$$
\text { Rasio Belanja Operasional }=\frac{541 \cdot 340 \cdot 247.599,00}{656.765 .137 .306,00}
$$$$
=0,824 \text { atau } 8,24 \%
$$

Rasio Belanja Modal $=\frac{114.219 .892 .457,00}{656.765 .137 .306,00}$ $=0,173$ atau $1,73 \%$

Berikut hasil perhitungan rasio keserasian daerah Pemerintah Kabupaten Pinrang tahun 2012-2014:

Tabel 3. Hasil Perhitungan rasio keserasian daerah Pemerintah kabupaten Pinrang Tahun $2012-2014$

\begin{tabular}{lll}
\hline Tahun & $\begin{array}{l}\text { Rasio Belanja } \\
\text { Operasional }\end{array}$ & Rasio Belanja Modal \\
\hline 2012 & $79,7 \%$ & $20,3 \%$ \\
\hline 2013 & $79,6 \%$ & $20,4 \%$ \\
\hline 2014 & $82,4 \%$ & $17,8 \%$ \\
\hline Rata-rata & $80,5 \%$ & $19,5 \%$ \\
\hline
\end{tabular}

Sumber: Data Diolah (2016) 
Banyaknya manfaat yang diperoleh apabila pelaksanaan belanja pembangunan dapat dilaksanakan secara mandiri ternyata belum mampu dirasakan oleh pemerintah Kabupaten Pinrang. Hal ini terbukti dengan hasil perhitungan rasio keserasian Kabupaten Pinrang tahun anggaran 2012-2014 yang menunjukkan masih rendahnya rasio belanja pembangunan apabila dibandingkan dengan rasio belanja rutin. Dimana, hasil rata-rata dari rasio belanja pembangunan sebesar $19,50 \%$ dan rata-rata rasio belanja rutin sebesar $19,50 \%$, terdapat gap sebesar $61 \%$.

Sesuai dengan UU No 33 Tahun 2004 pasal 10 disebutkan bahwa yang menjadi sumbersumber pembiayaan untuk pembangunan daerah (capital investment) antara lain berasal dari PAD dan Dana Perimbangan yang diterima oleh daerah-daerah dari Pemerintah Pusat. Dana Perimbangan itu sendiri terdiri dari Dana Bagi Hasil, Dana Alokasi Umum (DAU), Dana Alokasi Khusus (DAK). Selain itu juga ada sumber lain yang berasal dari pembiayaan berupa pinjaman Daerah.

Meskipun terdapat banyak sumber-sumber pembiayaan untuk pembangunan daerah berdasarkan UU No 33 Tahun 2004 pasal 10, namun faktanya pemerintah Kabupaten Pinrang yang lebih condong pada ekonomi kerakyatan belum memperhatikan pembangunan daerah, walaupun belanja pembangunan naik meskipun relatif kecil. Hal ini dikarenakan keterbatasan dana yang dimiliki oleh pemerintah sehingga pemerintah lebih berkonsentrasi pada pemenuhan belanja rutin yang mengakibatkan belanja pembangunan untuk pemerintah Kabupaten Pinrang kecil atau belum terpenuhi.

\section{d. Rasio Pertumbuhan}

Rasio pertumbuhan (growth ratio) mengukur seberapa besar kemampuan Pemerintah daerah dalam mempertahankan dan meningkatkan keberhasilan yang telah dicapai dari periode ke periode berikutnya. Rumus yang digunakan untuk menghitung Rasio pertumbuhan adalah sebagai berikut:

$r=\frac{P n-P o}{P o} \times 100 \%$

Pn = Data yang dihutung pada tahun ke-n Po Pertumbuhan

$=$ Data yang dihitung pada tahun ke- $0 \mathrm{r}=$

Berikut perhitungan rasio pertumbuhan Pemerintah Kabupaten Pinrang tahun 20122014:

Tabel 4. Perhitungan Rasio Pertumbuhan Pemerintah Kabupaten Pinrang Tahun 2012-2014.

\begin{tabular}{|c|c|c|c|c|}
\hline \multirow[t]{2}{*}{ Komponen Pertumbuhan } & \multicolumn{4}{|l|}{ Tahun Anggaran } \\
\hline & 2011 & 2012 & 2013 & 2014 \\
\hline PAD & $13.465 .906 .862,91$ & $17.920 .619 .304,26$ & $21.176 .935 .131,33$ & $37.641 .158 .766,00$ \\
\hline Pertumbuhan & - & $24,86 \%$ & $15,38 \%$ & $43,74 \%$ \\
\hline Total Pendapatan & $539.233 .386 .170,44$ & $555.707 .823 .565,73$ & $637.684 .394 .059,15$ & $737.114 .981 .212,91$ \\
\hline Pertumbuhan & - & $2,96 \%$ & $12,86 \%$ & $13,49 \%$ \\
\hline Belanja Operasi & $401.511 .119 .469,00$ & $420.113 .701 .099,00$ & $468.987 .945 .106,00$ & $541.340 .247 .599,00$ \\
\hline Pertumbuhan & - & $4,43 \%$ & $10,42 \%$ & 13,36 \\
\hline Belanja Modal & $101.765 .523 .496,00$ & $92.859 .950 .409,75$ & $103.502 .560 .153,00$ & $114.219 .392 .457,00$ \\
\hline Pertumbuhan & - & $0,96 \%$ & $10,28 \%$ & $9,38 \%$ \\
\hline
\end{tabular}

Berdasarkan hasil perhitungan pada tabel 4 kondisi pertumbuhan APBD Kabupaten Pinrang dapat disimpulkan bahwa APBD pada tahun anggaran 20122014 menunjukkan pertumbuhan rata-rata yang negatif. Hal ini diakibatkan pertumbuhan nilai PAD dan total pendapatan daerah tidak diikuti oleh pertumbuhan belanja pembangunan. Artinya, pemerintah Kabupaten Pinrang belum mampu mempertahankan dan meningkatkan pertumbuhannya dari periode yang satu ke periode berikutnya yang disebabkan masih fluktuatifnya pertumbuhan belanja pembangunan, dan belanja rutin yang terus bertambah. Dengan mengetahui pertumbuhan masing-masing komponen sumber pendapatan dan pengeluaran, maka dapat dilakukan evaluasi terhadap potensi-potensi daerah yang perlu mendapat perhatian. Semakin tinggi persentase pertumbuhan setiap komponen pendapatan dan pengeluaran, maka semakin besar kamampuan Pemerintah daerah dalam mempertahankan dan meningkatkan keberhasilan yang dicapai dari setiap periode.

\section{KESIMPULAN DAN SARAN}




\section{Kesimpulan}

Dari hasil penelitian dan hasil analisis data dapat diambil kesimpulan sebagai berikut:

a. Rasio kemandirian keuangan daerah selama lima tahun terakhir yang menghasilkan jumlah rata-ratanya sebesar 3,97\% dengan pola hubungan yang instruktif. Dari hasil tersebut, tergambar dengan jelas masih besarnya ketergantungan pemerintah Kabupaten Pinrang terhadap sumber-sumber dana bantuan dari pihak ekstern, baik dari pemerintah pusat maupu dari pemerintah provinsi, dengan komponen bantuan terbesar adalah Dana Alokasi Umum (DAU) dan Dana Penyesuaian.

b. Berdasarkan kemampuan PAD untuk membiayai pengeluaran rutin daerah, yang sering disebut juga dengan Rasio IKR (Indeks Kemampuan Rutin) ratarata hanya sebesar 5,047\% dengan pola kemampuan keuangan yang masih berada dalam interval $00,01 \%-20,00 \%$ yang dinilai sangat kurang. Artinya, PAD Kabupaten Pinrang belum mampu membiayai belanja rutin.

c. Berdasarkan hasil perhitungan rasio keserasian, pemerintah Kabupaten Pinrang masih lebih memprioritaskan belanja rutin daripada belanja pembangunan. Hasil ratarata dari rasio pembangunan sebesar $19,50 \%$ dan rasio belanja rutin sebesar 80,50\%. Terdapat kesenjangan sebesar $61 \%$. Angkaangka ini menunjukkan bahwa pemerintah daerah belum memperhatikan pembangunan daerah.

\section{Saran}

Berdasarkan hasil analisis data dan kesimpulan tentang kinerja keuangan Pemerintah Kabupaten Pinrang, penulis mencoba mengajukan beberapa saran. Saransaran tersebut adalah sebagai berikut:

a. Pelaksanaan otonomi daerah sebagaimana dinyatakan dalam UU Nomor 32 tahun 2004 sebagai revisi dari UU Nomor 22 tahun 1999, sangat diperlukan kemandirian keuangan daerah agar tingkat ketergantungan keuangan daerah kepada pemerintah pusat dapat dikurangi melalui intensifikasi Pendapatan Asli Daerah yang dilakukan oleh masingmasing daerah.

b. Mengingat terbatasnya jumlah dan jenis sumber-sumber Pendapatan Asli Daerah, maka diperlukan penyerahan beberapa sumber keuangan nasional yang potensial untuk dikelola dan dipungut sendiri oleh daerah dan menjadi penerimaan PAD.

c. Penelitian ini hanya dilakukan pada tahun anggaran 2012-2014 di Kabupaten Pinrang saja, diharapkan untuk penelitian selanjutnya obyek penelitiannya dilakukan dibeberapa Kabupaten/Kota sehingga terdapat perbandingan antara Kabupaten/Kota yang satu dengan Kabupaten/Kota yang lain.

\section{REFERENSI}

Abdullah S. Sistem Pengendalian Internal Pemerintah: Perlukah? Atau, Mengapa? (online)(http://syukriy.wordpress.com/20 08/10/19/sistem-pengendalianinternalpemerintah-perlukah-atau-mengapa/), diakses 2015.

Abdullah S. Daya Serap Anggaran Rendah Masalah Desentralisasi Fiskal. (online) (http://syukriy.wordpress.com/2009/01/2 1/daya-anggaranrendahmasalahdesentralisasi-fiskal-daerah), diakses 18 januari 2015.

Elim J, Safral M. 2009. Lingkungan Pengendalian. Jakarta: Pusdiklatwas BPKP. Haryanto, Arifuddin, Sahmuddin. 2007. Akuntansi Sektor PublikSemarang: Badan Penerbit Universitas Diponegoro.

Hasmah R. Menyongsong penerapan SPIP: Menuju tata kelola pemerintah yang lebih baik. (online) (http://www.bappenas.go.id/blog/?p=29), diakses18 januari 2012.

Kabupaten Pinrang Dalam Angka 2009. 2009. Muna: Badan Pusat Statistik Kabupaten Pinrang.

Mamesah, DJ. 1995. Sistem Administrasi Keuangan Daerah. Jakarta: Gramedia Pustaka Utama.Pedoman Pengelolaan Keuangan Daerah. 2006. Jakarta Penerbit CV TamitaUtama.

Soeseno K. 2009. Pedoman Teknis Umum Penyelenggaraan Sistem Pengendalian Intern Pemerintah. Jakarta: Badan Pengawasan Keuangandan Pembangunan 
AMNESTY: JURNAL RISET PERPAJAKAN

p-ISSN: 2714-6308 | e-ISSN: 2714-6294

pp: 1-8, Volume 1, Nomor 1, Mei 2018

Suparmoko M. 2002 Ekonomi Publik untuk

Keuangan \& Pembangunan Daerah.

Yogyakarta: Penerbit Andi.

Yuwono S, Utomo DC, Zein S, R Azrafiani A.

2008. Memahami APBD dan

Permasalahannya (Panduan

Pengelolaan Keuangan Daerah).

Malang: Bayumedia Pulishing.

Widayadi D. 2008. Abstraksi Peraturan Pemerintah Republik Indonesia Nomor 60 Tahun 2008 tentang Sistem Pengendalian Intern Pemerintah \& PeranBPKP. Makassar: Perwakilan BPKP Provinsi Sulawesi Selatan. 